\title{
A fucan from the brown seaweed Spatoglossum schröederi inhibits Chinese hamster ovary cell adhesion to several extracellular matrix proteins
}

H.A.O. Rochal,

C.R.C. Franco ${ }^{2,3}$,

E.S. Trindade ${ }^{3}$,

L.C.M. Carvalho',

S.S. Veiga' ${ }^{2}$ E.L. Leite ${ }^{1}$,

C.P. Dietrich ${ }^{3}$ and H.B. Nader ${ }^{3}$

\author{
${ }^{1}$ Departamento de Bioquímica, Universidade Federal do Rio Grande do Norte, \\ Natal, RN, Brasil \\ 2Departamento de Biologia Celular, U niversidade Federal do Paraná, \\ Curitiba, PR, Brasil \\ ${ }^{3}$ Departamento de Bioquímica, Escola Paulista de Medicina, \\ Universidade Federal de São Paulo, São Paulo, SP, Brasil
}

\section{Correspondence \\ H.B. Nader \\ Departamento de Bioquímica EPM, UNIFESP \\ Rua 3 de Maio, 100, 4ํandar 04044-020 São Paulo, SP \\ Brasil \\ Fax: + 55-11-573-6407 \\ E-mail: hbnader.bioq@epm.br \\ Presented at \\ SIMEC 2000 - International \\ Symposium on Extracellular \\ Matrix, Angra dos Reis, RJ, \\ Brazil, September 24-27, 2000. \\ Research supported by FAPESP CAPES and CNPq.}

Received September 22, 2000 Accepted March 6, 2001

\section{Abstract}

Fucans, a family of sulfated polysaccharides present in brown seaweed, have several biological activities. Their use as drugs would offer the advantage of no potential risk of contamination with viruses or particles such as prions. A fucan prepared from Spatoglossum schröederi was tested as a possible inhibitor of cell-matrix interactions using wild-type Chinese hamster ovary cells (CHO-K1) and the mutant type deficient in xylosyltransferase (CHO-745). The effect of this polymer on adhesion properties with specific extracellular matrix components was studied using several matrix proteins as substrates for cell attachment. Treatment with the polymer inhibited the adhesion of fibronectin to both CHO-K1 $\left(2 \times 10^{5}\right)$ and CHO-745 $\left(2 \times 10^{5}\right.$ and $5 \times$ $10^{5}$ ) cells. No effect was detected with laminin, using the two cell types. On the other hand, adhesion to vitronectin was inhibited in CHO-K1 cells and adhesion to type I collagen was inhibited in CHO745 cells. In spite of this inhibition, the fucan did not affect either cell proliferation or cell cycle. These results demonstrate that this polymer is a new anti-adhesive compound with potential pharmacological applications.

\section{Introduction}

Fucan is a term used to define a family of L-fucose-containing sulfated polysaccharides with extremely variable molecular weights. They are extracted from the extracellular matrix of brown seaweed (1), the jelly coat of sea urchin eggs (1), and the body wall of the sea cucumber (2).

Since the first description of the fucan from algae, these polysaccharides have been
Key words

- $\mathrm{CHO}$ cells

- Extracellular matrix proteins

- Fucan

- Glycosaminoglycans

- Cell adhesion

- Brown algae tested for biological activities in different mammalian systems. Alga fucans have antiviral (3), anti-ulcer and anti-adhesion activity (4), anticoagulant activity $(1,5)$, anti-inflammatory activity, and antiproliferative and antitumoral properties. They are inhibitors of vascular smooth muscle cell and fibroblast proliferation and can block sperm-egg binding in several species (6). The structures of these fucans vary among species and sometimes among different parts of the plant (7). 
On the other hand, in contrast to animal fucans, alga fucans have portions of other neutral sugars and uronic acids in addition to sulfate and fucose in their structures. This complexity led Grauffel et al. (5) to propose that the chemical composition of the different polysaccharides may vary according to the method of extraction. Thus, each new fucan purified is a unique compound with unique structural features and thus a potential new drug.

\section{Structural features of fucans}

The structural characteristics of sulfated fucans responsible for all these biological activities have not been determined and consequently the relationships between structural and biological activities have not been clearly established. Most of the difficulties for these studies arise from the fact that these compounds are highly heterogeneous polysaccharides which give complex nuclear magnetic resonance (NMR) spectra with broad signals hampering resolution (1). In fact, for these plant polysaccharides even high-field NMR is of limited value, and complete descriptions of their structures are not available at present (2). However, meaningful structural studies using NMR are possible with relative low molecular weight (LMW) fucans that have been prepared by several methods such as acid hydrolysis of high molecular weight $(\mathrm{HMW})$ fucans $(8,9)$ or extration from brown seaweeds (10).

Studies with LMW fucans obtained by chemical hydrolysis of HMW fucans have demonstrated that 3-and/or 4-linked fucose residues are always present, sulfation at the 2 and 4 positions can also be identified in these polymers and their biological activities are apparently related not only to molecular weight and sulfation, but also the quantity and position of the sulfated residues in the compound $(1,6,8)$. Recently, Nagaoka et al. (4), using data from partial acid hydrolysis, methylation and NMR analysis, proposed the average structure of a $56-\mathrm{kDa}$ fucan. Although chemical hydrolysis is important to determine the structure of fucans, it can cause structural alterations such as debranching or desulfation. Only enzymatic methods can cleave glycosidic linkages specifically without modifying the structural units present in the original polysaccharide. However, no commercial endofucosidases are available. The extraction of LMW fucans from brown seaweed, which have biological activity, would be very important to determine the structure/biological activity relationships of fucans.

Dietrich et al. (7) have fractionated fucans from three types of brown seaweeds using the same methodology for the characterization and quantitation of the different classes of glycosaminoglycans (11). They have demonstrated that these seaweeds contain three main fucans with distinct electrophoretic mobilities which were named $\mathrm{A}, \mathrm{B}$ and $\mathrm{C}$ according to their relative mobility. A $21-\mathrm{kDa}$ LMW fucan with mobility equal to that of fucan A was extracted from the brown algae Spatoglossum schröederi (10) using the same methodology. This fucan is composed of a core of $\beta$ (1-3) glucuronic acid-containing oligosaccharide of $4.5 \mathrm{kDa}$ with branches at C-4 of fucose chains $\alpha$ (1-3) linked. The fucose is mostly substituted at C-4 with sulfate groups and at $C-2$ with chains of $B(1-4)$ xylose, which, in turn, is also partially sulfated. Recently, using this methodology we have also purified a fucan with the mobility of fucan B from the same alga (12). This compound differs from the A fucan by the presence of significant amounts of galactose.

Here we describe the effect of this fucan on cell proliferation, cell cycle and adhesiveness of both wild-type Chinese hamster ovary cells (CHO-K1) and xylosyltransferase-deficient mutant (CHO-745) to several extracellular matrix proteins. In the mutant the synthesis of both heparan and chondroitin sulfates is diminished. The glycosaminoglycans synthesized by mutant 745 were 
about $5 \%$ of those produced by wild-type cells (13). CHO-K1 cells are tumorigenic whereas $\mathrm{CHO}-745$ mutant cells are not (13).

\section{Cell proliferation and fucans}

Cell proliferation is a physiological process regulated by a broad range of growth factors and cytokines such as fibroblast growth factor. It has been reported that anionic polysaccharides such as heparin and fucans, due to their highly negative charge bind to several growth factors (6) and this binding is thought to have an important regulatory role (either stimulatory or inhibitory) on cell proliferation.

Fucans were shown to be anti-angiogenic and to inhibit smooth muscle (14) and endothelial cell growth (15). In addition, LMW fucan affects smooth muscle cell growth in a time- and dose-dependent, reversible and nontoxic fashion. It acts after internalization, arresting cells at the $\mathrm{G}_{0} / \mathrm{G}_{1}$ phase of the cell cycle (14).

The growth of several tumor cells is affected by fucans $(16,17)$. Studies performed with the non-small-cell human bronchopulmonary carcinoma line (NSCLC-N6) have shown that an HMW fucan exhibits an inhibitory effect both in vitro and in vivo (18). Fibroblasts (CCL 39) show 80\% inhibition of proliferation in the presence of LMW fucan at a concentration of $1000 \mu \mathrm{g} / \mathrm{ml}$. This inhibition does not exceed $50 \%$ of human colon adenocarcinoma cells and has no detectable effect on lymphocytic leukemia (P388) or human breast adenocarcinoma (MCF7, MCF7ras). This action is reversible and is not related to any modification of the cell distribution during various phases of the cell cycle (17). However, it is related to the chemical structure of the osidic units and to the extent of sulfation of the polymer.

The present studies with LMW B fucan from $S$. schröederi against tumorigenic $\mathrm{CHO}-$ $\mathrm{K} 1$ cells and nontumorigenic $\mathrm{CHO}-745$ cells did not show any modification of the cell distribution during the phases of the cell cycle (Figure 1A) when quiescent cultures of both cell lines were incubated with $\left[{ }^{3} \mathrm{H}\right]-$ thymidine $(0.25 \mu \mathrm{Ci} / \mathrm{ml}), 10 \% \mathrm{FCS}$ and fucan
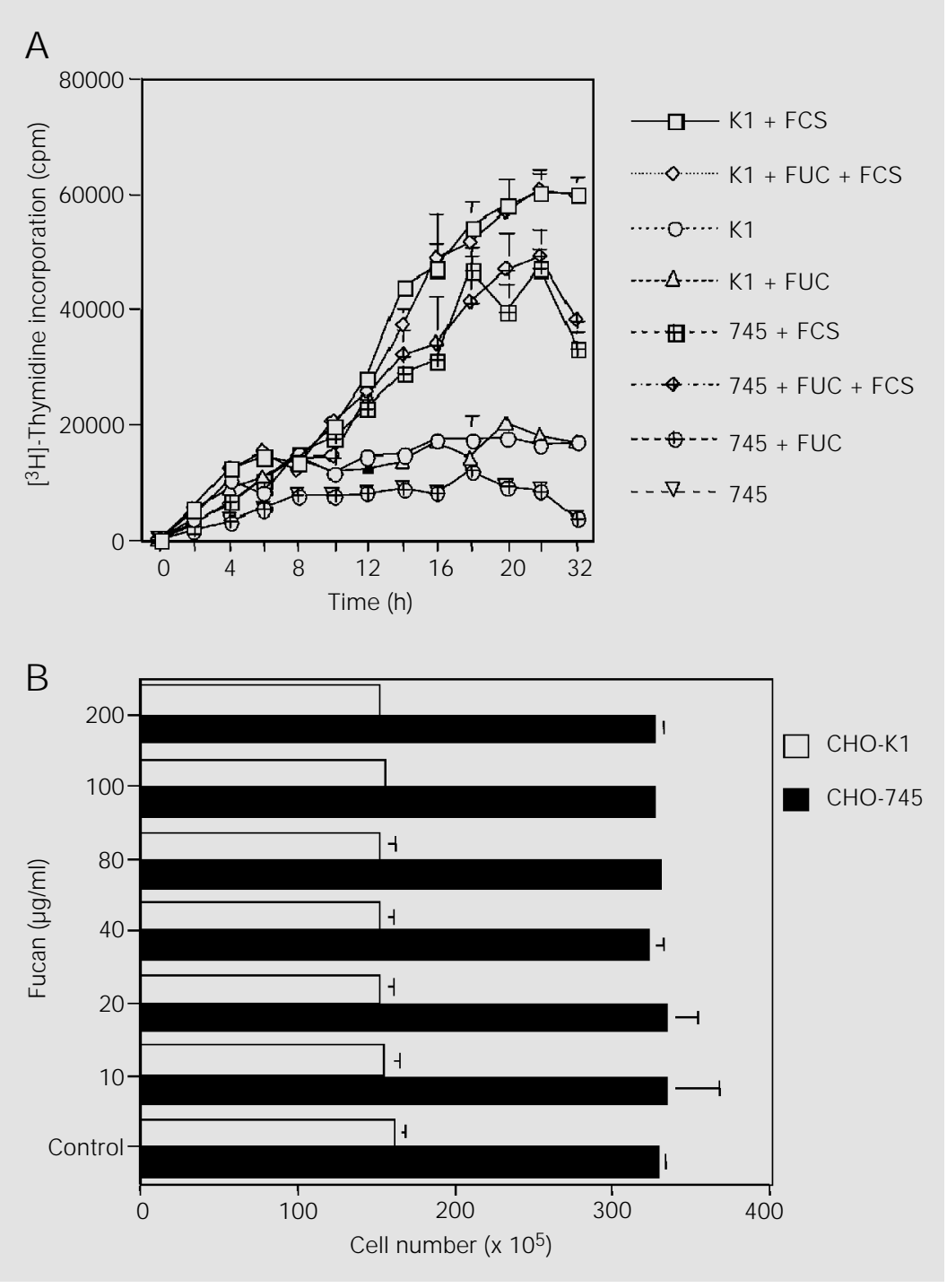

Figure 1. Thymidine incorporation and proliferation of $\mathrm{CHO}$ cells in the presence of fucan $\mathrm{B}$ from Spatoglossum schröederi. A, Thymidine incorporation into $\mathrm{CHO}$ cells in the presence of fucan. $\mathrm{CHO}$ cells were maintained in $\mathrm{F}-12$ medium supplemented with $10 \%$ FCS at $37^{\circ} \mathrm{C}, 2.5 \% \mathrm{CO}_{2}$. For the incorporation of $\left[{ }^{3} \mathrm{H}\right]$-thymidine, quiescent cultures were incubated with $\left[{ }^{3} \mathrm{H}\right]$-thymidine $(0.25 \mu \mathrm{Ci} / \mathrm{ml})$ for the times indicated and radioactivity was determined by scintillation counting. Data are reported as the mean \pm SD of four determinations. FUC - Fucan B. B, Effect of different fucan concentrations on the growth of $\mathrm{CHO}$ cells. Growth-arrested cells were released from the $\mathrm{G}_{0}$ phase by the addition F-12 medium plus $10 \%$ FCS in the absence (control) or in the presence of the indicated concentrations of fucan. The initial cell number was $3 \times 10^{5}$ cells/plate. After incubation at $37^{\circ} \mathrm{C}$ for 5 days in a $2.5 \% \mathrm{CO}_{2}$ atmosphere, the cells (in triplicate plates) were harvested after "viocase" treatment and cell number was determined. Values are reported as the mean \pm SD of triplicate determinations. 
$(100 \mu \mathrm{g} / \mathrm{ml})$. Moreover, no inhibitory or stimulatory effects on cell proliferation were observed using fucan concentrations of 10 to $200 \mu \mathrm{g} / \mathrm{ml}$ (Figure 1B). However, anti-adhesive effects were observed with the same concentrations of fucan.



Figure 2. Effect of fucan on $\mathrm{CHO}$ cell adhesion to different matrix proteins. $\mathrm{CHO}$ cells, $2 \mathrm{x}$ $10^{5}$ or $5 \times 10^{5}$, in $100 \mu \mathrm{l}$ or $250 \mu$ of cell suspension, respectively, were seeded on plastic plates coated with extracellular matrix proteins. The cells and fucan $(100 \mu \mathrm{g} / \mathrm{ml})$ were added simultaneously to $500 \mu \mathrm{l}$ of F-12 medium containing $100 \mu \mathrm{g} / \mathrm{ml}$ fucan. CHO cells were stained with crystal violet. $\mathrm{CHO}$ cells that adhered to the surface at the indicated times were used as a measure of cell adhesion. The data are reported relative to the values in the absence of fucan, as means \pm SD of four determinations. LN - laminin; FN - fibronectin; VN - vitronectin; Col I - type I collagen.

\section{Anti-adhesive fucans}

Cell adhesion has been shown to involve interactions between substrate components and cell surface molecules; however, knowledge concerning the detailed biochemistry of these events is limited. This is because adhesion is a complex process involving several steps including initial attachment, mobilization of the cytoskeleton and subsequent spreading. These steps are likely to be mediated by different sets of molecules and signals. In addition, different cell types respond to a given substrate in different ways.

The detachment of arrested tumor cells and their recirculation out of a given organ site are important aspects of metastasis, but this does not necessarily indicate that implantation in the microcirculation and metastatic colonization will follow. Mechanical arrest, stable attachment and adhesion of malignant cells to normal tissues may be necessary to prevent spontaneous detachment, recirculation and eventual cell death by continued circulatory mechanical trauma. Tumor cells tend to migrate to the basement membranes where they adhere more strongly. In fact, the invasion of tumor cells through basement membranes and adhesion to matrix proteins (laminin, fibronectin, vitronectin, etc.) are the crucial steps in the formation of metastasis. Thus, drugs inhibiting cell adhesion should theoretically prevent the formation of metastasis.

Soeda et al. (19) reported an inhibition of Lewis lung carcinoma cell attachment to laminin in the presence of HMW fucans; however, no effect was detected for type IV collagen or fibronectin. An HMW fucan from Sargassum stenophyllum blocked attachment of the carcinoma cells to laminin, vitronectin and type IV collagen by $86.4,53.6$ and $28.0 \%$, respectively (20). Chemical analysis has shown that sulfates and uronic acid groups are critical for the anti-adhesive activity of this fucan. LMW fucans specifically inhibit the adhesion of McCoy fibroblast cells and 
decrease thrombospondin production in COLO 320 DM cells (17).

In the present study, the ability of the wild-type and mutant $\mathrm{CHO}$ cells to interact with exogenous proteins, e.g., fibronectin $(\mathrm{FN})$, laminin $(\mathrm{LN})$, vitronectin $(\mathrm{VN})$ and type I collagen ( $\mathrm{Col} \mathrm{I})$ in the presence of the LMW fucan $(100 \mu \mathrm{g} / \mathrm{ml})$ from $S$. schröederi was tested in a cell adhesion assay.

Cell attachment is a time-dependent reaction which is also affected by the concentration of cell surface receptors and ligands. Thus, we have examined the attachment of $\mathrm{CHO}$ cells to wells coated with matrix proteins $(10 \mu \mathrm{g} / \mathrm{ml})$ during three different periods of time with two different cell concentrations, i.e., $2 \times 10^{5}$ and $5 \times 10^{5}$ (Figure 2). Regardless of the number of wild-type and mutant $\mathrm{CHO}$ cells, fucan did not show antiadhesive activity when laminin was used as the substrate. However, the fucan presented an anti-adhesive effect on $2 \times 10^{5}$ wild-type $\mathrm{CHO}$ cells when vitronectin was used as a substrate and on $2 \times 10^{5} 745$ mutant $\mathrm{CHO}$ cells when type I collagen was used as a substrate. No effect was observed with $5 \mathrm{x}$ $10^{5}$ cells in either case.

It is interesting to note that when fibronectin was used as the substrate, fucan acted as an anti-adhesive molecule with both cell types at $2 \times 10^{5}$ cell concentration. This is the first report of a fucan inhibiting cell attachment to fibronectin. We are presently investigating other possible activities of this fucan that produce physiological alterations in $\mathrm{CHO}$ cells.

The glycosaminoglycans heparin and heparan have demonstrated anti-adhesive activity on several cell lines. Since polysaccharides are extracted from animal tissues, they are potentially contaminated with viruses or unconventional particles such as those present in bovine spongiform encephalopathy. Because the fucans can mimic the effects of heparin and heparan sulfate they may be safe substitutes of these glycosaminoglycans as pharmacological agents.

\section{References}

1. Pereira MS, Mulloy B \& Mourão PAS (1999). Structure and anticoagulant activity of sulfated fucans. J oumal of Biological Chemistry, 274: 7656-7667.

2. Mulloy B, Mourão PAS \& Gray E (2000). Structure/function studies of anticoagulant sulphated polysaccharides using NMR. J ournal of Biotechnology, 77: 123135.

3. Schaeffer DJ \& Krylov VS (2000). Anti-HIV activity of extracts and compounds from algae and cyanobacteria. Ecotoxicology and Environmental Safety, 45: 208-227.

4. Nagaoka M, Shibata H, Kimura-Takagi I, Hashimoto S, Kimura K, Makimo T, Aiyama R, Ueyama S \& Yokokura T (1999). Structural study of fucoidan from Cladosiphon okamuranus TOKIDA. Glycoconjugate J ournal, 16: 19-26.

5. Grauffel V, Kloareg B, Mabeu S, Durand P \&J ozefonviczJ (1989). New natural polysaccharides with potent antithrombotic activity: fucans from brown algae. Biomaterials, 10: 363-369.
6. Boisson-Vidal $C$, Haroun $F$, Ellouali $M$, Blondin C, Fischer AM, Agostini A \& J ozefonvicz J (1995). Biological activities of polysaccharides from marine algae. Drugs of the Future, 20: 1237-1249.

7. Dietrich CP, Farias GGM, Abreu LRD, Leite ED, Silva LF \& Nader HB (1995). A new approach for characterization of polysaccharides from algae: Presence of four main acidic polysaccharides in three species of the class Phaeophycea. Plant Science, 108: 143-153.

8. Chevolot L, Foucault A, Chaubet F, Kervarec N, Sinquin C, Fisher A \& BoissonVidal C (1999). Further data on the structure of brown seaweed fucans: relationships with anticoagulant activity. Carbohydrate Research, 319: 154-165.

9. Chizhov AO, Dell A, Morris HR, Haslam SM, McDowell RA, Shashkov AS, Nifantev NE, Khatuntseva EA \& Usov AI (1999). A study of fucoidan from the brown seaweed Chorda filum. Carbohydrate Research, 320: 108-119.
10. Leite ED, Medeiros MGL, Rocha HAO, Farias GGM, Silva LF, Chavante SF, Abreu LRD, Dietrich CP \& Nader HB (1998). Structure and pharmacological activities of sulfated xylofucoglucuronan from the alga Spatoglossum schröederi. Plant Science, 132: 215-228.

11. Dietrich CP, Sampaio LO \& Toledo OMS (1976). Characteristic distribution of sulfated mucopolysaccharides in invertebrates. Biochemical and Biophysical Research Communications, 71: 1-10.

12. Rocha HAO, SilvaTMA, Alves LG, Queiroz KCS, Alves AP, Mourão PAS, Leite EL, Dietrich CP \& Nader HB (1999). Characterization of the new fucan from the brown algae Spatoglossum schröederi. XXVIII Annual Meeting of the Sociedade Brasileira de Bioquímica e Biologia Molecular, Caxambu, MG, Brazil, May 23-26, 110 (Abstract).

13. Esko J D, Rostand KS \& Weinke J L (1988). Tumor formation dependent on proteoglycan biosynthesis. Science, 241: 1092- 
1096.

14. Logeart D, Pringent-Richard S, J ozefonviczJ \& Letourneur D (1997). Fucans, sulfated polysaccharides extracted from brown seaweeds, inhibit vascular smooth muscle cell proliferation. I. Comparison with heparin for antiproliferative activity, binding and internalization. European J ournal of Cell Biology, 74: 376-384.

15. Giruax J, Matou S, Bros A, TaponBretaudiere J, Letourneur D \& Fisher A (1998). Modulation of human endothelial cell proliferation and migration by fucoidan and heparin. European J ournal of Cell Biology, 77: 352-359.

16. Zhuang C, Itoh H \& Mizuno T (1995). Anti- tumor active fucoidan from the brown seaweed, Umitoranoo (Sargassum thumbergii). Bioscience, Biotechnology and Biochemistry, 59: 563-567.

17. Ellouali $M$, Boisson-Vidal $C \&$ J ozefonvicz $J$ (1994). Effect and interaction of fucans with cells. Colloids and Surfaces. B: Biointerfaces, 2: 305-314.

18. Riou D, Colliec-J ouault S, DuSel DP, Bôsch S, Siavoshian S, Bert V, Tomasoni $C$, Sinquin C, Durand P \& Roussakis C (1996). Antitumor and antiproliferative effects of a fucan extracted from Ascophyllum nodosum against a nonsmall-cell bronchopulmonary carcinoma line. Anticancer Research, 16: 1213-1218.
19. Soeda S, Ishida S, Shimeno $S \&$ Nagamatsu A (1994). An inhibition effect of oversulfated fucoidan on invasion through reconstituted basement membrane by murine Lewis lung carcinoma. J apanese J ournal of Cancer Research, 85: 11441150.

20. Stevan $F R$, Veiga $S S$, lacomine $M$, Oliveira MBM \& Duarte MER (2000). Effects of fucans from Sargassum stenophyllum on HeLa cell adhesion. XXIX Annual Meeting of the Sociedade Brasileira de Bioquímica e Biologia Molecular, Caxambu, MG, Brazil, May 27-30, 108 (Abstract). 